\title{
The Role of Windbreaks in Attracting the Useful Avifauna - Case Study: Moara Domnească Didactic Farm
}

\author{
Cosmin-Alexandru MIHAI*, Florin STĂNICĂ \\ ${ }^{1}$ University of Agronomic Sciences and Veterinary Medicine of Bucharest, Faculty of Horticulture, \\ 59 Mărăşti Blvd., 011464, Bucharest, Romania \\ *corresponding author: mcosminalexandru@yahoo.com
}

Bulletin UASVM Horticulture 75(1) / 2018

Print ISSN 1843-5262, Electronic ISSN 1843-536X

DOI:10.15835/buasvmcn-hort: 003117

\begin{abstract}
"Moara Domnească" is a didactic farm belonging to the University of Agronomic Sciences and Veterinary Medicine of Bucharest. Moara Domnească has an area of 520 ha, of which 65 ha of orchard. The orchard, but also a major part of the farm has a wind protection system consisting of windbreaks planted in 1920's with English Oak (Quercus robur), Ash (Fraxinus excelsior), Norway Maple (Acer platanoides), and other species of shrubs from the spontaneous flora. Since 1860, Romania has become one of the first countries in the world to have developed forest windbreaks and shelterbelt. Both the establishment of windbreaks and scientific research have been specifically designed to limit the negative effects of the extreme continental climate. Even the windbreaks benefits are multiple and clear, their extension was limited in many areas where are extremely needed. Based on the ornithological observations carried out between 2015-2016, we found out that the forest windbreak plays an extremely important role on the orchard ecosystem, influencing positively the life of wild birds that find food, shelter and nesting places throughout the year.
\end{abstract}

Keywords: birds, wind shelters, orchard

\section{Introduction}

In 1860, the great agronomist and political figure Ion Ionescu de la Brad took notice the necessity to found the first windbreaks for "shading against the wind". This initiative places Romania among the first countries in the world taking action against desertification and improving the environment conditions for the agricultural cultures (Giurgiu and Seceleanu, 2014).

In 1920's, another personality of the Romanian agriculture - Constantin Garoflid, was actively involved in the promotion and plantation of windbreaks especially in the Great Romanian Plain (Ionescu et al., 2011).

In general, the windbreaks occupy approximately $3 \%$ from the surface of an exploitation, and the increases in production (for cereals) are estimated at about 35-55\% (Popescu, 2017), what means that in a short time the costs of the occupied surface (that means sometimes degraded land), setting up and maintenance are liquidated.

In the current context - of durable agriculture and of environmental protection - the windbreaks, the grassed bands and the artificial constructions for wildlife, are a part of the agro ecological infrastructure for conservation and protection of the useful biodiversity.

If the windbreaks are so necessary for the improvement of the environment conditions, having as a result significant increases in production, how much would the economic output increase if we would take into account also 


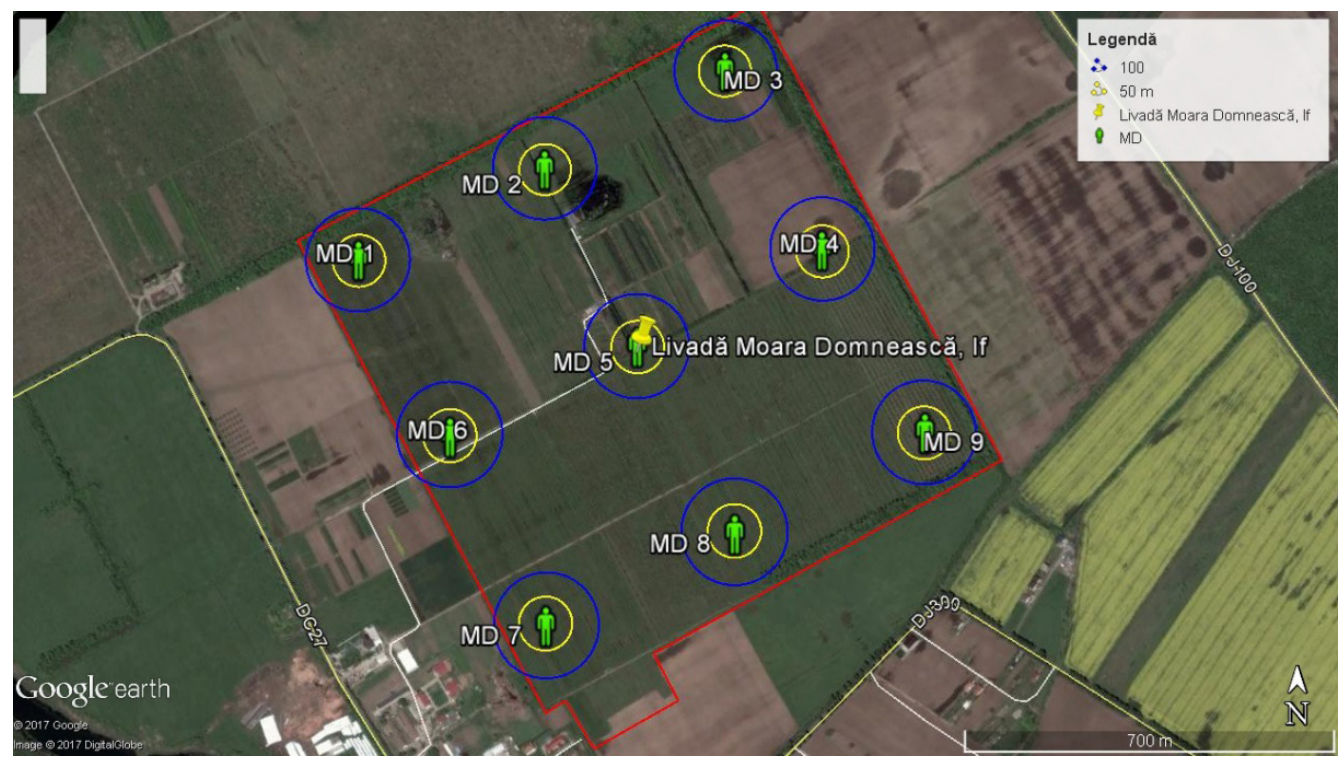

Figure 1. Observation points map from the orchard of Moara Domnească didactic farm, Ilfov county

the positive effects of the useful biodiversity in cultivated plants protection?

\section{Materials and methods}

The applied methodology was that used in elaborating the National Report in 2013, presented to European Union regarding the stage and structure of bird populations specific for agricultural lands (Zoltan and Domşa; 2014). and also professional methodology according to Brunn et al. (1999), Jay et al. (2000), Lesaffre (2007), Svensson et al. (2009), Neşu (2012), Ricard et al. (2012), S.O.R. (2015), Tomescu and Muşat (2017).

The main purpose of the protocol was to investigate all the bird species that are specific for agricultural lands and their number in the selected squares.

This methodology was applied to diurnal birds that are spread in medium and large density in the terrestrial habitats.

\section{Experiment localization}

Moara Domnească Didactic Farm is the property of the University of Agronomic Sciences and Veterinary Medicine of Bucharest and is located at $15 \mathrm{~km}$ of Bucharest in Moara Domnească, Ilfov County.

The orchard and a part of the farm have a protection system of windbreaks made from English Oak (Quercus robur), Ash (Fraxinus excelsior), Norway Maple (Acer platanoides),
Hawthorn (Crataegus monogyna), Common Spindle Tree (Euonymus europaea), Dog Rose (Rosa canina) and other shrubs species from the spontaneous flora. The windbreak was planted in 1920's and it protects the 65 ha of orchards on three sides (North-West, North-East, South-East).

The delimitation of the surface in study was done using the program Garmin Base Camp, and the observation points in Google Earth Pro.

Around each point marked on the map from MD1 to MD9, can be observed two circles that represent $50 \mathrm{~m}$, respective $100 \mathrm{~m}$ distance from the chose point. The distance between two points of observation was $400 \mathrm{~m}$ (Fig. 1).

The map and the observation points have been uploaded on Garmin Vista Cx GPS, that was always used in the field trips in order to have a correct position on the observation points.

Before the actual counting, a half of the day was spent in the field to map the habitat, using the map and the sheet for each observation point. Then, were made sketches in the field journal indicating the size and the type of habitat, localizing the $50 \mathrm{~m}$ and $100 \mathrm{~m}$ distances from the observation point.

In each observation point were spent exactly 5 minutes and were noted the identified species and the number of birds heard around the observation point in three categories:

- Inside the circle with the size of $100 \mathrm{~m}$, the birds sitting on the ground, on the vegetation or landing during the 5 minutes observation period. Also, 
Table 1. List of the species observed in the orchard of Moara Domnească didactic farm in November 2015 - October 2016

\begin{tabular}{|c|c|c|c|c|c|}
\hline No. & Name & Statute & No. & Name & Statute \\
\hline 1 & White Stork (Ciconia ciconia) & $\mathrm{S}$ & 29 & Collared Dove (Streptopelia decaocto) & $\mathrm{R}$ \\
\hline 2 & Hawfinch (Coccothraustes coccothraustes) & $\mathrm{R}$ & 30 & House Martin (Delichon urbicum) & $\mathrm{S}$ \\
\hline 3 & Dunnock (Prunella modularis) & $\mathrm{R}$ & 31 & Robin (Erithacus rubecula) & $\mathrm{R}$ \\
\hline 4 & Nightjar (Caprimulus europaeus) & $S$ & 32 & Collared Flycatcher (Ficedula albicollis) & $\mathrm{S}$ \\
\hline 5 & Common Tern (Sterna hirundo) & $S$ & 33 & Lapwing (Vanellus vanellus) & $\mathrm{S}$ \\
\hline 6 & Chaffinch (Fringilla coelebs) & $\mathrm{R}$ & 34 & Wren (Troglodytes troglodytes) & $\mathrm{R}$ \\
\hline 7 & Rook (Corvus frugilegus) & $\mathrm{R}$ & 35 & Blue Tit (Cyanistes caeruleus) & $\mathrm{R}$ \\
\hline 8 & Hooded Crow (Corvus cornix) & $\mathrm{R}$ & 36 & Great Tit (Parus major) & $\mathrm{R}$ \\
\hline 9 & Black Woodpecker (Dryocopus martius) & $\mathrm{R}$ & 37 & Wood Pigeon (Columba palumbus) & $\mathrm{R}$ \\
\hline 10 & $\begin{array}{c}\text { Great Spotted Woodpecker (Dendrocopos } \\
\text { major) }\end{array}$ & $\mathrm{R}$ & 38 & Quail (Coturnix coturnix) & $S$ \\
\hline 11 & Skylark (Alauda arvensis) & $\mathrm{S}$ & 39 & Yellowhammer (Emberiza citrinella) & $\mathrm{R}$ \\
\hline 12 & Fieldfare (Turdus pilaris) & $\mathrm{W}$ & 40 & Nightingale (Luscinia megarhynchos) & $\mathrm{S}$ \\
\hline 13 & Yellow Wagtail (Motacilla flava) & $\mathrm{S}$ & 41 & Hoopoe (Upupa epops) & $\mathrm{S}$ \\
\hline 14 & Black Redstart (Phoenicurus ochruros) & $\mathrm{S}$ & 42 & Chiffchaff (Phylloscopus collybita) & $\mathrm{S}$ \\
\hline 15 & Raven (Corvus corax) & $\mathrm{P}$ & 43 & Barn Swallow (Hirundo rustica) & $\mathrm{S}$ \\
\hline 16 & Cormorant (Phalacrocorax carbo) & $\mathrm{S}$ & 44 & Mallard (Anas platyrhynchos) & $\mathrm{R}$ \\
\hline 17 & Magpie (Pica pica) & $\mathrm{R}$ & 45 & Lesser Whitethroat (Sylviacurruca) & $\mathrm{S}$ \\
\hline 18 & Cuckoo (Cuculus canorus) & $\mathrm{S}$ & 46 & Hobby (Falco subbuteo) & $\mathrm{S}$ \\
\hline 19 & Swift (Apus apus) & $\mathrm{S}$ & 47 & Common Buzzard (Buteo buteo) & $\mathrm{R}$ \\
\hline 20 & Roller (Coracias garrulus) & $\mathrm{S}$ & 48 & Grey Heron (Ardea cinerea) & $\mathrm{R}$ \\
\hline 21 & Little Egret (Egretta garzetta) & $\mathrm{S}$ & 49 & Red-backed Shrike (Lanius collurio) & $\mathrm{S}$ \\
\hline 22 & Icterine Warbler (Hippolais icterina) & $\mathrm{S}$ & 50 & Goldfinch (Carduelis carduelis) & $\mathrm{R}$ \\
\hline 23 & Pheasant (Phasianus colchicus) & $\mathrm{R}$ & 51 & Sparrowhawk (Accipiter nisus) & $\mathrm{R}$ \\
\hline 24 & Greenfinch (Chloris chloris) & $\mathrm{R}$ & 52 & Kestrel (Falco tinnunculus) & $\mathrm{S}$ \\
\hline 25 & Jay (Garrulus glandarius) & $\mathrm{R}$ & 53 & Tree Sparrow (Passer montanus) & $\mathrm{R}$ \\
\hline 26 & Green Woodpecker (Picus viridis) & $\mathrm{R}$ & 54 & House Sparrow (Passer domesticus) & $\mathrm{R}$ \\
\hline 27 & Golden Oriole (Oriolus oriolus) & $\mathrm{S}$ & 55 & Grey-headed Woodpecker (Picus canus) & $\mathrm{R}$ \\
\hline 28 & Starling (Sturnus vulgaris) & S & 56 & Spotted Flycatcher (Muscicapa striata) & $S$ \\
\hline
\end{tabular}

were jotted down the birds that were in flight a longer time above the studied circle - because they are associated with the studied habitat in a certain way (e.g. Skylark). The Barn Swallows, the Martins and the Swifts were jotted down just if they visited their nests. The birds have been noted in two distance categories $(0-50 \mathrm{~m}$ and $50-100$ $\mathrm{m})$ and have been noted only in the circle where they have been seen or heard for the first time. All observations were put down on the paper localized approximately in the place where they have been observed.

- Birds flying above the observed area without landing;
- Birds observed outside the 100-m circle.

- During the observations, the observer stayed still for 5 minutes continuously and when needed the binocular Nikon Prof Staff S 8x42 was used.

- In order to limit the birds' disturbance, the observations were made by one observer.

- The bird species observed while moving from one point to another and that have not been put down during the 5 minutes, were put down separately.

- The observations were done monthly, from November 2015 to November 2016. According to the methodology, between the observations had to be minimum 14 days. 


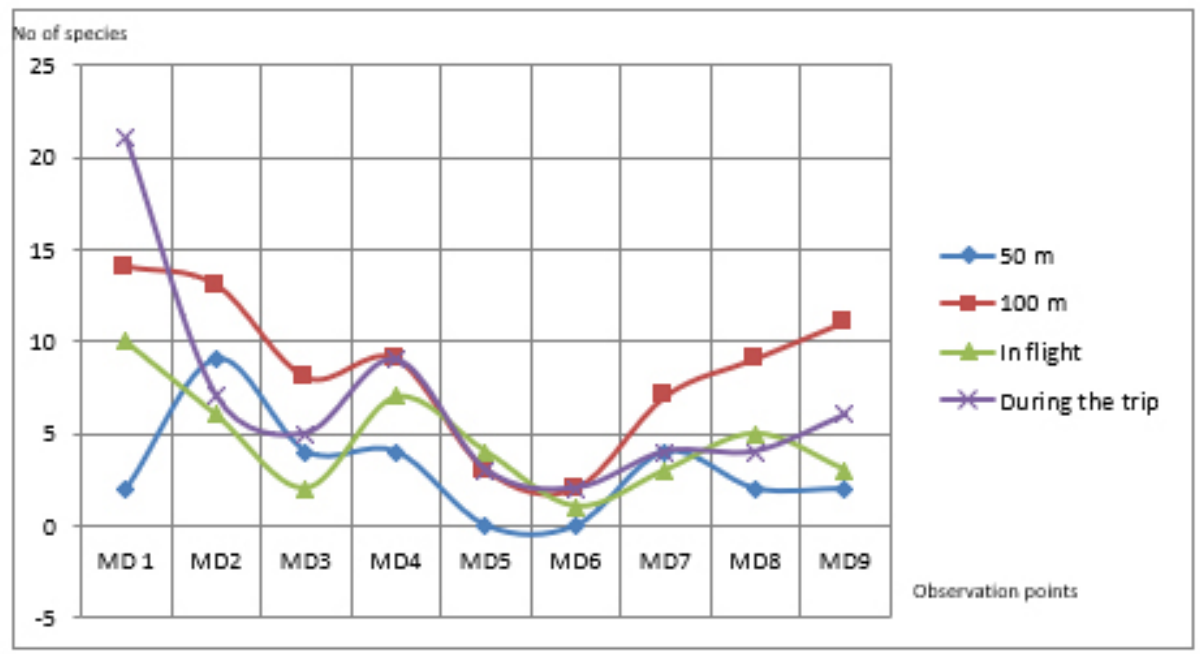

Figure 2. Effect of the windbreaks in attracting the additional avifauna in the orchard of Moara Domnească didactic farm

- The counting had to take place the earliest possible in the morning ( 5 a.m. in summer) and had to finish before $10 \mathrm{a} . \mathrm{m}$. because the birds are more active in this period of the day. If it was a rainy day or strong winds, the observations were postponed.

The utilized Equipment was represented by:

- Nikon ProStaff s 8x42 binoculars;

- Watch;

- „Birds of Europe” Field Guide, second edition. Svensson L, Mullarney K., Zetterstrom D. Princeton Field Guides, 2009;

- Field journal;

- GPS (track-log ON) Garmin Vista Cx;

- Suitable clothing: impermeable footwear, seasonable and camouflage clothing.

In order to apply this observations procedure, the observer needs to know very well the common bird species from Romania - including their songs and twitters.

The methodology allows that the obtained data to be used for census or in the case of many years observations to be used to identify the population tendencies, calculating the Farmland Bird Index (FBI), index used in European Union studies.

\section{Results and discutions}

In the studied orchard while mapping the observation points were identified 6 types of habitats:
- Agricultural lands cultivated with cereals;

- Alignment forest;

- Windbreaks;

- Meadows;

- Dendrological nursery;

- Orchard.

The orchard occupies about $85 \%$ of the total surface, based on the measurements done with Google Earth.

During the year have been observed 56 bird species (Tab. 1) - 28 species of resident birds (R), 27 species of summer visitors (S), and 1 winter visitor (W).

From the observation points were collected data representing the number of birds observed during the year from 50 meters, 100 meters, in flight and during the trip.

In MD1, MD2, MD3, MD4 the number of bird species is relatively constant while in MD5 and MD6 the number of species is lower compared to the other observation points (Fig. 2).

MD5 point is situated at about $450 \mathrm{~m}$ from the windbreaks, close to the access road.

MD6 is situated at about $800 \mathrm{~m}$ from the windbreaks at North-East, $650 \mathrm{~m}$ from the windbreaks at South-East and $450 \mathrm{~m}$ from MD1 point and of the windbreaks at North-West.

The largest number of species observed in 50 $m$ is at point MD2. A possible explanation is that in that area the birds have been fed during the winter months and there 7 artificial nests have been mounted being after that $100 \%$ occupied. 
The number of observed bird species in 50 $100 \mathrm{~m}$ is zero in MD5 and MD6 observation points because these points were to a distance bigger than $200 \mathrm{~m}$ than the windbreaks.

The number of observed bird species grows when the observation are closer to windbreaks (MD8 and MD9).

MD7 although is not surrounded of windbreak, the number of species is quite large because of the artificial nests mounted in that area, occupied $100 \%$ although the birds were not fed during the winter.

- Close to MD3 point, in the windbreak in February 2017 an artificial nest for Kestrel (Falco tinnunculus) was mounted and it was immediately occupied in April 2017. In the nest, 5 juveniles were observed.

- In 2016 and 2017 close to MD9 observation point at about $1000 \mathrm{~m}$ from MD3, in an abandoned corvid nest, a family of Common Buzzard (Buteo buteo) nested, but the nest was located too high in order to find out the number of juveniles in the nest.

- In other occasions, in the orchard also night birds as Little Owl (Athene noctua) and Long-eared Owl (Asio otus) were observed.

These results confirm the observation made by Jay et al. (2000), Lesaffre (2007), Neşu (2012), Ricard et al. (2012), S.O.R. (2015), Tomescu and Muşat (2017) and highlight that windbreaks are extremely useful in attracting useful fauna.

\section{Conclusion}

From the 56-bird species observed, 28 are residents, majority being insectivores.

The presence of woodpeckers in the orchard is due to the old trees present in the windbreaks (over 100-year-old). The woodpeckers are bio indicators and make their own nests in thicker trees. These nests are occupied in the next years by the birds that nest in tree holes but do not build their nests (e.g. Great Tit - Parus major).

In the observation points that are close to the windbreaks, were observed even 14 species in the same area while in MD5 and MD6 that are at a distance of $450-800 \mathrm{~m}$ from the windbreak, the number of species observed in the same place was maximum 3.

The number of species observed in MD4, compared with that in MD5 and MD6 may indicate the fact that the efficiency of windbreaks in attracting the additional avifauna is of 400-500 $\mathrm{m}$. The territory occupied by the small birds vary between 50 and 200 meters around the nest.

In MD2, where some birds were constantly fed during the winter and artificial nests were mounted, the birds were more tolerable with the observer's presence during the observations thus being observed 9 species in 50 meters.

In MD7, missing the windbreak was compensated for mounting the artificial nests in a satisfactory proportion.

The raptors, as Common Buzzard (Buteo buteo) and Kestrel (Falco tinnunculus) need high trees for nesting and the presence of the corvids or artificial nests in those trees.

Kestrel (Falco tinnunculus) generally occupies easily the artificial nests, mounted at 7-8 meters high.

The birds present in the windbreak may act as a biological filter concerning the expansion of the pest insects on the closer field that sometimes cannot be maintained in good conditions.

\section{References}

1. Brunn B, Delin H, Svensson L, Singer A, Zetterstrom D, adapt. Munteanu D (1999). Păsările din România și Europa. Determinator ilustrat. Octopus Publishing Group Ltd.

2. Giurgiu V, Seceleanu I (2014). Perdelele forestiere de protecție în contextul asigurării securității ecologice și alimentare. Dezbatere științifică "Sistemul național al perdelelor forestiere de protecție, între deziderat și realizare". Academia Română și ASAS. http://www.asas.ro/wcmqs/academia/ manifestari-stiintifice/1.\%20SECURITATE_ECOLOGICA_ PERDELE.pdf Accessed 29.06.2017.

3. Ionescu MR, Stănică F, Mihai CA (2011). Birds - Unpaid Workers in the Fruit Orchard, International Conference on Sustainable Agriculture and Food Security - Challenges and Opportunities (ICSAFS 2011), Universitas Padjadjaran, Bandung, Indonesia, 27-28 September.

4. Jay M, Barataud M, Besancon T, Hentz JL, Delattre P, Noblet JF, Schwaab F, Tupinier Y (2000). Oiseaux et mammiferes, auxiliaires des cultures. Chirat, Paris.

5. Lesaffre G (2007). Le traite rustica des oiseaux du jardin. Graficas Estella en Espagne, Paris.

6. Neşu I. (2012). Perdelele forestiere de protecție a culturilor agricole - o necesitate. Revista de Silvicultură și Cinegetică. Anul XVII, 20: 56-58.

7. Popescu V (2017). Am avut cândva perdele forestiere de protecție... Revista Lumea Satului, 9: 46-47.

8. Ricard JM, Garcin A, Jay M, Mandrin JF (2012). Biodiversité et regulation des ravageurs en arboriculture fruitière, Ed. CTIFL.

9. Societatea Ornitologică Română (S.O.R.) și Asociația pentru Protecția Păsărilor și a Naturii „Grupul Milvus” (2015). Atlas al speciilor de păsări de interes comunitar din România (Atlas 
of communitarian interest bird species). Editura Noi Media Print.

10. Svensson L, Mullarney K, Zetterström D (2009). Birds of Europe. Second Edition. Princeton University Press.

11. Tomescu R, Muşat I (2017). Experiența românească în realizarea perdelelor forestiere de protecție.,http://www. asas.ro/wcmqs/academia/manifestari-stiintifice/3.\%20 Experienta\%20romaneasca\%20in\%20realizarea\%20 perdelelor $\% 20$ forestiere $\% 20 \mathrm{de} \% 20$ protectie.pdf Accessed 29.06.2017.

12. Zoltan SD, Domșa C (2014). Societatea Ornitologică Română şi Asociaţia pentru Protecţia Păsărilor şi a Naturii „Grupul Milvus". Ghid standard de monitorizare a speciilor de păsări de interes comunitar din România. Editura Noi Media Print (p. 45). 